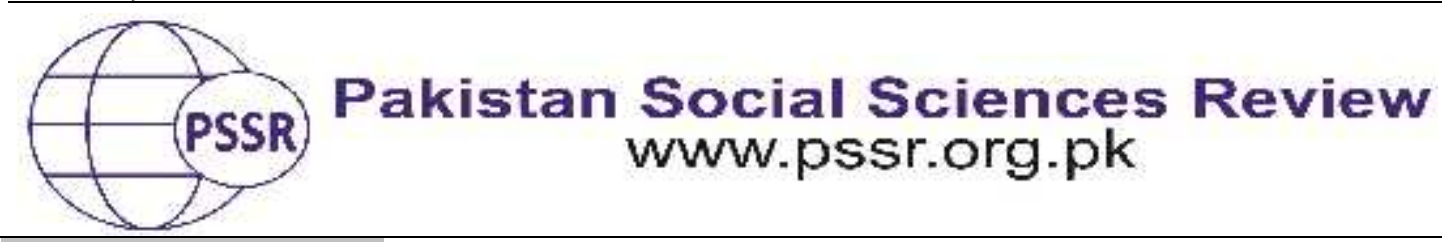

RESEARCH PAPER

\title{
A Critique of the Unrelenting Curse of Gender Discrimination in Pashtoon Society and the Way Out
}

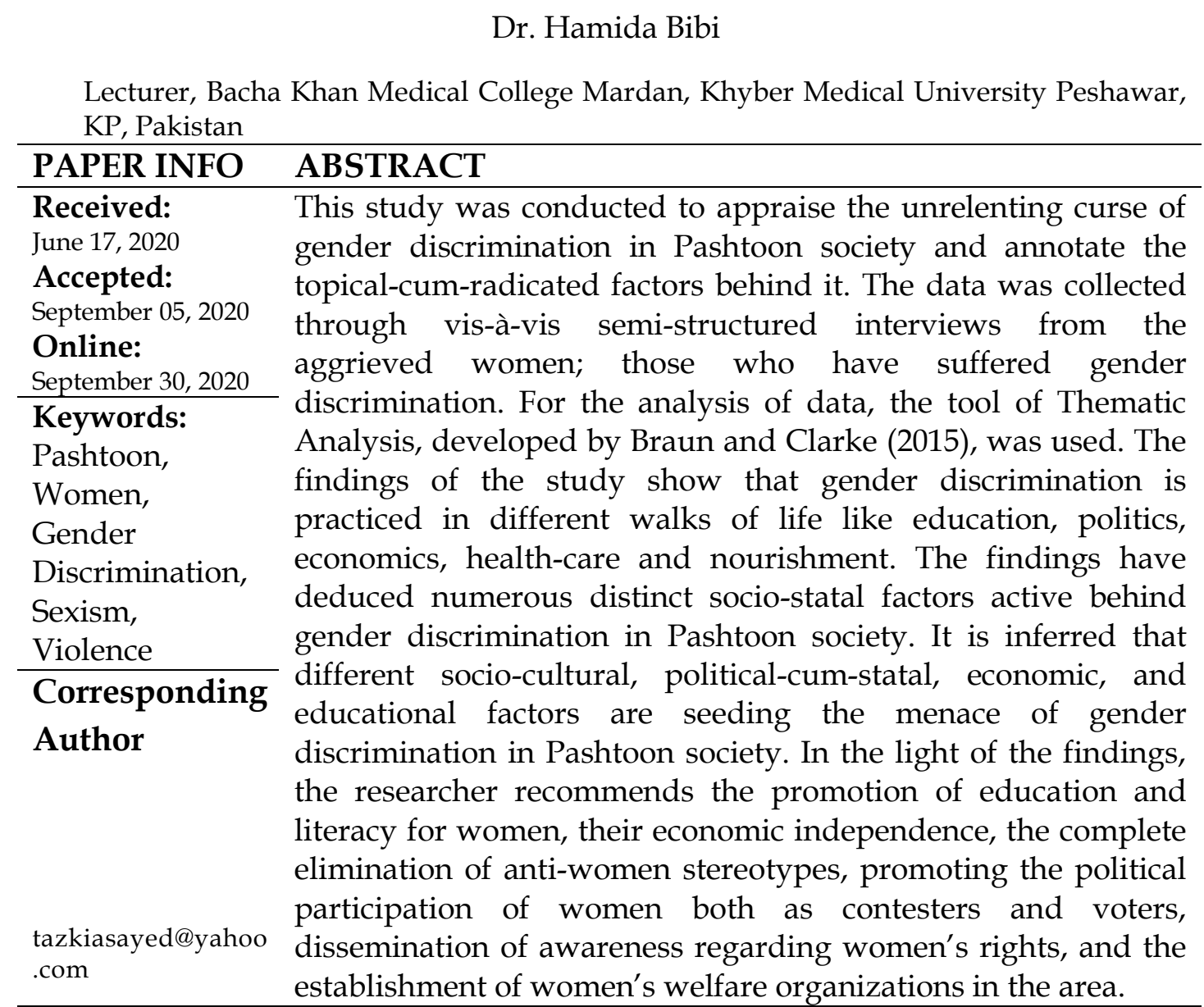

\section{Introduction}

According to Bhasin (2003), gender means "the socio-cultural definition of man and woman; the way societies distinguish men and women and assign them different social roles". Gender and sex vary: the former is dynamic, socio-cultural, man-made and variable, while the later is innate, biological, natural and constant, with particular, respectively, social and biological identities ascribed. Having varying roles to perform, men work as family-heads, property caretakers, breadwinners and politicians, while women nourish children and look after the households. 
For Biber, Carger and Hesse (2000), "Gender is socially determined; it refers to the meaning which is assigned to both male and female socially. Every society assigns particular roles to each sex". For Montgomery and Borgata (2000), "Women and men are taught to be different in behaviors, roles, emotions and attitudes". This discourse is produced to exert and maintain power, especially to legitimize and rationalize the unjust resources' distribution. For IFAD (2000), "gender relations refer to a complex system of personal and social relations of domination and power through which women and men are socially created and regulated giving them access to power and material resources or are allocated status within society".

For Pilcher and Whelehan (2004), sexism refers to the unjust treatment of women owing to their gender. In the course of this practice, people and societies dominate one gender over the other dispensing institutional, legal, educational, political, economic and social privileges unequally. Dubbed as gendered, these societies treat women and men unjustly in the different walks of life like politics, property, education, etc.

For Anderson (2004), masculinity and femininity means male-dominance and women-subordination respectively. It is stereotypically believed that men are more compentent and logical than women. for Beauvoir (19949), the frequent attribution of these hallmarks have made them indispensable and innate. This discourse of these attributions was used to justify women's subordination.

For Istikomah (2015), gender discrimination has varying kinds: (a) marginalization: it refers to the kind of discrimination in which a specific gender is forbidden to partake in or perform a social or religious role. (b) Subordination: it refers to the kind of discrimination in which specific genders are given inferior and subordinate positions. (c) Stereotypes: in this type, a gender, especially female gender, is labeled negatively. (d) Violence: women are abused and humiliated psychologically, sexually or physically. For Brundtland (2002), in order to help women get rid of this menace, women-education should be disseminated which is efficacious in changing women's mindset and behavior about gender discrimination. Uneducated women are easily controlled, abused and influenced.

For Kumari (2012), in varying degrees and kinds, sexism is practiced around the world. It is practiced in various forms: (a) Natality Inequality: refers when boys are given more preference over girls. The birth of boys is celebrated, while abortions are practiced in case of female fetuses. (b) Ownership Inequality: refers to the practice in which women are disinherited or they are not given their due property. (c) Household Inequality: in this kind of discrimination, men are given better care at home rather than women.

According to Annandale (1996), in order to obliterate gender discrimination and violence against women and improve their status in society, women shall be given, firstly, political rights enabling them to raise their fundamental issues on legal platforms; and, secondly, women education shall be improved increasing their 
chances of employment, self-dependence, and, besides, increasing women's awareness regarding their rights and privileges. For Karnakata (2016), economic dependence have always compelled women to bear up men's violence and discrimination. In order to be powerful, women should be made economically independent.

For Jayachandran (2014), sexism is more prevalent in developing countries like Indonesia, Bangladesh and India denying women's rights in family, politics, education, law and health care. In such gendered countries, men possess power to regulate women's education and mobility. Besides denying the right of education for women, they are given poor health care and few opportunities of employment and economic independence. All this denial of educational and economic opportunities has downright increased women's illiteracy and dependence on men. A number of socio-economic factors have been radicating sexism and violence against women. As women are the true incarnation of honor and family-pride, men regulate their mobility, especially in the context of education and employment, in order to avoid their harassment. Owing to the waxing poverty in the area, parents cannot afford better health care and education of their female kids. For Agha (2016), women shall be empowered politically and economically in order to help them combat sexism and the gendered societal disposition.

\section{Material and Methods}

The current study was conducted in Tehsil Katlang, District Mardan, KP, Pakistan. In order to get accurate and reliable data, resentful women, the aggrieved sufferers of gender discrimination, were interviewed for data collection. A sample of 20 people was taken through purposive sampling method. The interviewees were all married women having kids. Fearing their male counterparts and social taboos, it took onerous efforts on behalf of the researcher to persuade these women for interview. After suffering gender discrimination themselves, these women were now experiencing it being inflicted upon their daughters. Due to the social taboos and cultural restrictions, factitious names were given to all the interviewees. Semistructured in-depth interview was used as research tool for data collection. For the analysis of data, the tool of Thematic Analysis, developed by Braun and Clarke (2015), was used.

\section{Results and Discussion}

The data analysis implies that future expectation from male kids compels parents to prefer their male children. "A male offspring is given preference because of the social and traditional importance given to a male child, and because it is felt that it is the son who will look after the parents in their old age and perform the last rites after their death" reported Salma, a 31 years old mother to 04 kids. "Societies prefer the birth of boys more than girls and as a result female feticide has become a daily practice. There are many reasons why societies prefer male birth over female. Some people believe that boys will enhance the status of their families both socially and financially. They will look after their families and parents. Some people donot 
prefer female kids because of the fear of dowry" narrated Gul Rukh, a 23 years old mother.

The findings also reveal that sexism exists in health cares. "Higher importance is given to the health of a son than a daughter. Sons are given more and better food, and girls are given the leftovers" narrated Shawkata, a 44 years old mother to 7 kids. "Men are well fed", reported 21 years old Azra, "well dressed and better cured whenever they are ill, whereas women feed over leftovers". "Financial expectations from boys also compel their parents to give them better health care's", storied Rahmania, a mother to 03 kids.

Sexism prevails in the field of education. "Parents often prefer educating their sons rather than their daughters in the hope that the son will earn and support the family in the future" outlined Begum Naveeda, a mother to 05 kids. Boys are sent to standard institutions, whereas girls education is ignored. "it is a common belief that there is no benefit to educate a girl child when she cannot go outside to work and earn money" narrated Wahida, a mother to 04 kids. The fact of future expectation from boys to earn and economically support their families compels parents to prefer their schooling. Besides, "Many parents do not send their female children to schools just because of poverty", narrated Zohra bibi.

Sexism exists in politics and political institutions. "in our society, whether today or in the past, men enjoy greater positions. Politics are associated with men. Women have always had it hard in this country to participate in politics" reported Shakeela. "Women are also not dominant in politics because of the lack of higher education. Different stereotypes have also created hurdles for women to take part in politics. This distance from politics and law has given to men the opportunity to make patriarchal laws. These laws favor men and marginalize women in different walks of life" reported Roheena.

\section{Findings of the Study}

The findings of the study are as under:

\section{Socio-Cultural factors}

The findings of the study show that some traditionally practiced sociocultural factors - various stereotypes - are active behind sexism. Under these stereotypes, women are labeled as incompetent and irrational beings, while, on the contrary, men to be more competent and rational. Pertinently, social roles are assigned in the light of these stereotypes. Men are preferred in employment, business, politics, while women to arrange the households. In the light of their services, men are given good care and nourishment, while women are marginalized.

In Pashtoon code of life, women are the true embodiments of honor and family pride. Fearing their abuse and harassment, a girl's schooling and stay outside 
home is downright considered a threat to the family. People regulate the mobility of women in order to avoid their harassment and abuse. Besides, the early marriage of girls is considered another way to avoid mishaps.

Another factor revealed by the data is Patrilocality. As women have to depart and become someone's other property after their marriages, parents think it futile to educate women. Secondly, Patrilineality, a system in which the property and family names are named after men, has been serving as a factor behind sexism.

Another upsetting factor revealed by the data is the misinterpretation of the religious teachings used to stat sexism. Albeit the fact that they regulate women's mobility, religions do not discourage women's education and employment. Rather, they preach gender equality desisting violence against women.

\section{Illiteracy}

It is inferred by the data that illiteracy produces sexism as uncivilized cultures are less tolerant and liberal of women's rights. As uneducated men are unaware of human rights and propriety, they are more violent against women. Contrarily, cultured and civilized societies are more tolerant and liberal of women's rights. These societies support women's education and employment. The findings also reveal the fact that uneducated women are unaware of law and human rights subsequently tolerating sexism and violence silently. This attitude of tolerance encourages men for more oppression. Besides, uneducated women adopt the policy of condonement and appeasement regarding sexism and violence increasing the degree of these social evils. Being illiterate, uneducated women are unaware of the judicial steps they can take to hunt down sexism and violence. Illiteracy - being a hurdle in the employment and economic independence of women - keeps women dependent on men. Men exploiting women's dependence, keep them away from education and employment increasing their unemployment, poverty, and dependency on men.

\section{Judiciary and Law Enforcing Agencies}

The findings of the study reveal that there is some mismanagement in the judiciary or law enforcing agencies. The judiciary and law enforcing agencies are passive condoning the violence and discrimination against women. Seeking an advantage out of this condonement, men are inflicting sexism and violence against women fearlessly.

\section{Economic Factors}

The findings of the study reveal that the economic dependence of women compels them to adopt the policy of appeasement and condonment against gender discrimination and violence. Injustice and oppression produce tolerance and patience in women. In Pashtoon code of life, men work outside, while women indoor managing household. Men lead business and property and earn money, whereas 
women remain downright economically dependent on men. This economic power and independence give men power to decide the family decisions and regulate its members. In the course of this societal mismanagement, women suffer as their rights are usurped and violated. It is thought futile to invest in women's education as women, after their marriages, become someone's other property.

For choosing the birth of only male children is another form of gender discrimination. Women are thought to be financial burdens on families. Some parents do not prefer female kids because of the fear of dowry. Resultantly, around the globe, the abortion of female foetuses is prevalent. Under-age marriages of girls also have its roots in the realm of economy. It is thought both to be socially unsafe and economically difficult for families to rear up women for longer. Resultantly, the timely marriages of women are thought safer. In the course of sexism, its condonement and passive tolerance, the ideology of patriarchy disseminates becoming part of culture and people's psyche.

\section{Conclusion and Recommendations}

This study was conducted to appraise the unrelenting curse of gender discrimination in Pashtoon society and annotate the topical-cum-radicated factors behind it. The study concludes a number of factors radicating gender discrimination. It is inferred that gender discrimination is practiced in different walks of life like education, politics, economics, health-care and nourishment. The findings have deduced numerous distinct socio-statal factors active behind gender discrimination in Pashtoon society. It is inferred that different socio-cultural, political-cum-statal, economic, and educational factors are seeding the menace of gender discrimination in Pashtoon society. It is also revealed by the study that gender discrimination is condoned and not limelighted before the law. This factor has increased gender discrimination. Besides, judiciary and law enforcing agencies are passive condoning gender discrimination.

In the light of the findings, the researcher recommends the promotion of education and literacy for women, their economic independence, the complete elimination of anti-women stereotypes, promoting the political participation of women both as contesters and voters, dissemination of awareness regarding women's rights, and the establishment of women's welfare organizations in the area. Above all, it is recommended that judiciary and law enforcing agencies should work in close proximity, avoiding bits of condonement, to strictly punish the offenders and promote women's livelihood. 


\section{References}

Agha, N. (2016). Social Security or Cultural Benefits. Asian Journal of Social Science, 46(1-2), 35-51.

Anderson, C. (2004). Women, Ideology and Violence: The Construction of Gender in the Book of the Covenant and Deuteronomic Law (Vol. 394). Bloomsbury Publishing.

Annandale, E., \& Clark, J. (1996). What is gender? Feminist theory and the sociology of human reproduction. Sociology of Health $\mathcal{E}$ Illness, 18(1), 17-44.

Baden, S., \& Reeves, H. (2000). Gender and development: Concepts and definitions (p. 28). Bridge.

Beauvoir, S. d. (1949). The Second Sex. France: Vintage Classics.

Bhasin, K. (2003). Understanding Gender. New Delhi: Women Unlimited.

Borgatta, E.F. \& Montgomery, R.J.V. (2000). Encyclopedia of Sociology (2nd ed., Vol. 2). New York: Macmillan Reference, USA.

Brundtland, G. H. (2002). Integrating Gender Perspectives in the Work of WHO. Retrieved from World Health Organization: http://www.who.int/genderequity-rights/knowledge/a78322/en/

Clarke, V., Braun, V., \& Hayfield, N. (2015). Thematic analysis. Qualitative psychology: A practical guide to research methods, 222-248.

Hesse-Biber, S. \& Carger, G. L. (2000). Working women in America: Split dreams. New York: Oxford University Press.

International Fund for Agricultural Development (IFAD). (2000) An IFAD approach to: Gender mainstreaming: The experience of the Latin America and the Caribbean division. Rome, Italy: U. Quintily S.p. A

Istikomah, N. (2015).women's attitudes towards gender discrimination in Khaled Hosseini's A Thousand Splendid Suns (Doctoral dissertation, Universitas Negeri Yogyakarta).

Jayachandran, S. (2015). The roots of gender inequality in developing countries. Economics, 7(1), 63-88.

Karnakata. (2016, October 09). Illiteracy seen as main reason for gender discrimination. Retrieved May 5, 2017, from The Hindu: http:/ / www.thehindu.com/todays-

Kumari, M. (2012). Women and Family Welfare. New Delhi: Random Publications.

Pilcher, J., \& Whelehan, I. (2004). 50 key concepts in gender studies. Sage. 